\title{
BOTULISM: A LABORATORY INVESTIGATION ON BIOLOGICAL AND FOOD SAMPLES FROM CASES AND OUTBREAKS IN BRAZIL (1982-2001) $)^{(1)}$
}

\author{
Dilma Scala GELLI(2), Miyoko JAKABI(2) \& Aldo de SOUZA(3)
}

\begin{abstract}
SUMMARY
Laboratory investigation of botulism from 1982 to 2001 confirmed the occurrence of eight positive outbreaks/cases of botulism in Brazil. From those, type A botulism was observed in seven of them. Biological material of one case (serum and feces) was positive in the first step of the bioassay, but the amount of sample was not sufficient for typification. One of the outbreaks that occurred in 2001 was negative for botulinum toxin in samples of serum, gastric washing and feces, collected eight days before the onset of the symptoms in the affected person who was clinically diagnosed as presenting the disease. Other two cases presenting compatible clinical diagnoses presented negative results. However, in those cases, the collection of samples was (1) after antiserum administration or (2) later than eight days of the onset of symptoms. Investigation was performed by mouse bioassay, as described in the Compendium of Methods for the Microbiological Examination of Foods (compiled by American Public Health Association - APHA) ${ }^{11}$, using specific antiserum from Centers for Disease Control (CDC), USA.
\end{abstract}

KEYWORDS: Human botulism; Botulinum toxin investigation; Botulinum toxin in Brazil.

\section{INTRODUCTION}

Botulism is a disease caused by toxins produced by Clostridium botulinum. This sporeformer anaerobic bacterium is naturally present in different environments such as soil, sediment of superficial water, fresh vegetables and spices. It can be isolated from different kinds of foods of animal and vegetable origin ${ }^{5,9,10,15,23}$. Four biological groups and eight types (A, B, C1, C2, D, E, F, and G) are recognized ${ }^{5,9,10,17,23}$, based on structural features, proteolytic activity and distinct antigenic toxins. There are evidences that toxin production is either mediated by a prophage $\left(C_{1}, D\right)$ or a plasmid $(G)^{17,23}$. Non-toxigenic strains are found in nature ${ }^{5,23}$, and a strain that produces both type $\mathrm{A}$ and $\mathrm{B}$ toxins ${ }^{23}$ has already been isolated. Type A and some type B and $\mathrm{F}$ strains are proteolytic; type $\mathrm{E}$, saccharolytic type B and $\mathrm{F}$ are non-proteolytic strains.

There are many intrinsic and extrinsic factors that may affect the growth of this bacterium in foods: it is a poor competitor when other autochthon microorganisms are present in the product; acid $\mathrm{pH}$ and some acidulants may inhibit or suppress its multiplication; water activity (Aw) under 0.93 is limitant, and the inactivation response at different high temperatures, as well to gamma irradiation treatment, is variable among vegetative cells and spores of different strains. Multiplication of proteolytic strains is inhibited at temperatures above $10{ }^{\circ} \mathrm{C}$, and that of non-proteolytic strains, above $3.3{ }^{\circ} \mathrm{C}^{3,4,5,7,8,9,10,13,20,23}$.

Types A, B, E and more rarely F, are related with human cases of botulism; type $\mathrm{G}$ may cause disease in primates, what indicates the possibility of affecting men ${ }^{5,18,23}$. Types A, B and F are mainly found in soils and the intestinal tract of terrestrial animals; type $E$ is found in marine aquatic environment ${ }^{5,9,11,13,15,21,22,23}$.

Four categories of botulism are recognized: classical or foodborne, due to ingestion of preformed toxin in foods; wound botulism due to production of toxin in vivo, in the infected wound; infant botulism due to $C$. botulinum colonization of the intestinal tract, in the absence of natural microbiota (children 3-6 months old) and undetermined botulism, involving persons in which no food or wound source is detected, and that may be also related with colonization of the intestines ${ }^{2}$. Symptoms in the affected person are similar in all categories and include generalized muscular weakness, visual disturbance, difficulty in speaking, extremely dry mouth, breathing difficulty, leading to respiratory failure, palpebral ptosis, dysphonia and urinary retention. At the beginning of the signs, intestinal manifestations may occur, including nausea, vomiting and severe constipation, what may be followed or not by transitory diarrhea.

Depending on the amount of toxin and the category of disease, sudden onset of symptoms may occur or not ${ }^{1,9,14,16,18,19,23}$. Outbreaks have been described in all continents. Although botulism is a relative rare disease, case fatality is high; from 1899 to $1995,1,026$ outbreaks were identified in the USA, involving 2,444 cases and 1,040 deaths ${ }^{20}$. In Argentine, according to ESCARTÍN (2000), 16 outbreaks were described from 1980 to 1989 : $77 \%$ caused by type A, $8 \%$ by B, and $0 \%$ by E, involving 36

(1) Performed in Food Microbiology Section, Central Laboratory, Instituto Adolfo Lutz, São Paulo, SP, Brasil

(2) From Food Microbiology Section, Central Laboratory, Instituto Adolfo Lutz, São Paulo, SP, Brasil

(3) From Food Microbiology Section, Central Laboratory, Instituto Adolfo Lutz, São Paulo, SP, Brasil. In memoriam

Correspondence to: Dra. Dilma Scala Gelli, Phone no.: 55-11-3068 29 32, Fax no.: 55-11-3085 35 05, e-mail: dilgelli@ial.sp.gov.br and dilmasgelli@hotmail.com 
affected persons, and 11 deaths. In the period between 1971 and 1989, 272 outbreaks were reported in the United States; $61 \%$ caused by type A, $21 \%$ by B and $17 \%$ by type E, with 597 cases and 11 deaths. In France, from 1978 to 1989,175 (0\% A, 97\% B and 2\% E) outbreaks were reported, with 304 cases and 2 deaths. In Denmark, in the 1984-89 period, there were 11 outbreaks ( $0 \% \mathrm{~A}$ and $\mathrm{B}$, and $100 \% \mathrm{E})$ with 16 cases and 12 deaths. Data available from these outbreaks indicate that fruits and vegetables by-products are common vehicles for botulism. In Argentine, fruit and vegetables by-products were responsible for $36 \%$ of the cases, compared with $29 \%$ due to meats and $21 \%$ due to fish. In the USA, among 294 outbreaks (1973-97), 128 were due to vegetablebased foods, 47 due to fish, 5 due to mushrooms, 5 due to no lacteous beverages, 16 due to meat-based foods, 3 due to Mexican style food, 47 related other kinds of foods and 43 were not identified ${ }^{5}$.

Botulinum toxins are thermolabile exoproteins (single dichain molecule of polypeptide, with molecular weight of approximately 150 Mdaltons). Produced as a pro-toxin, the toxic fraction is released by protease action; proteolytic strains can promote this release alone. For the non-proteolytic strains, the action of exogenous proteases, such as trypsin, is necessary. The toxin reaches the bloodstream and is disseminated into the body. No matter if ingested or produced in vivo, the toxin circulates in the body for 8-10 days after its release in bloodstream. Botulinum toxins are considered neurotoxins and their specific site of binding is the pre-synaptic cholinergic nerve in the muscle. Symptoms are associated with the blockage of acetylcholine release at the binding site of the toxin and the triggering of skeletal muscle contraction ${ }^{16,17,18,23}$.

Antitoxin administration do not release the toxin bound to the nervous terminal, but it is able to inactivate toxin circulating in the bloodstream, i.e., it prevents further binding of toxin and consequent exacerbation of symptoms. It is important to note that antitoxin administration does not lead to remission of symptoms already present. The illness may have a prolonged course, depending on the amount of bound toxin and may persist for more than 6 months $^{5,16,17,23}$.

Laboratorial investigation of cases and outbreaks of foodborne botulism is based on the evidence of toxin in biological samples collected from the affected person (serum, feces, gastric washing and other specimens) and leftovers of ingested foods. Extraction of the toxin is necessary in all kinds of samples, except serum. This is done by maceration in phosphate gel, overnight maintenance under refrigeration, followed by centrifugation. The supernatant is separated in three portions, in order to perform a presumptive laboratorial diagnosis. This first step is carried out for the demonstration of (1) the presence of the active substance that does not require trypsin activation (untreated portion); (2) the thermolabile characteristic (heat-treated portion); and (3) the presence of the pro-toxin (trypsin-treated portion). When (1) and/or (3) are positive, the definitive diagnostic step is the determination of the type of toxin, by inactivation with specific antiserum. The most reliable and sensitive method is the mouse bioassay: $0.5 \mathrm{ml}$ of serum and/or each portion extracted is intraperitoneally inoculated in at least two white mice (20-25 g weight). Positive result is the mice presenting symptoms within 4-72 h, depending on the amount of toxin injected. Symptoms include photophobia, difficult or elaborated breathing and death by respiratory arrest, what does not occur when the heat-treated portion is inoculated. When the pro-toxin is present, only the activated trypsin portion would show positive results. In vitro assays based on serological tests (radioimmunoassay, ELISA) and tissue cultures (human embryonic lung, HeLa, mouse fibroblast) are available, but the mouse bioassay remains as the reference test, for its sensitivity and specificity ${ }^{5,11,16,19,20,23}$.

Botulinum toxin is considered to be the most potent toxin known. Vaccination of laboratory staff is an important preventive measure, but it is not always feasible. Because of this, the collection, transport and investigation of samples must be conducted under strict safety rules. Samples must be held in an hermetical box, for they not to pose risk for the personnel responsible for transport and reception of the samples; all analytical steps must be conduced in a way to prevent aerosol production, and to preserve the biological structure and function of the toxin. Mouth pippeting is forbidden; all material that was in contact with the toxin has to be treated with a $1 \%$ chlorine solution. Separate physical area, trained personal, and adequate animal care (food, water supply) are basic requirements. Despite the use of an inactivation solution, all material, including dead animals, should be autoclave sterilized personally by the responsible investigators, before either disposal or washing. It is strongly suggested that the phone number and address of sites where antiserum treatment is performed is at hand, in case of laboratory accident. Botulinum toxin investigation ${ }^{19}$ should not be performed by only one professional working alone.

The objective of this study was to investigate the presence of botulinum toxin in samples sent to the Instituto Adolfo Lutz, from 1982 to 2001 .

\section{MATERIAL AND METHODS}

From 1982 to 2001, the Central Laboratory of Food Microbiology of Instituto Adolfo Lutz, SP, received samples for the investigation of botulinum toxin from different states of Brazil (Rio de Janeiro, Mato Grosso do Sul, Minas Gerais, São Paulo, Acre, Goiás Alagoas, Paraná and Tocantins). Samples were sent to the laboratory for diagnosis of the disease. The case history (symptoms, time of the onset of symptoms, ingestion of suspect foods, time between onset of symptoms and collection of biological samples, administration of antitoxin, etc.) was not frequently or completely informed to the laboratory.

The samples included food (leftovers from consumption; not consumed, unopened units of food), drugs (medicines), biological samples, such as blood, serum or clot, gastric washing, feces and pieces of organs obtained in the post-mortem examination. The total number of samples analyzed was 88 , among 40 suspect cases or outbreaks as follows: one in each year of 1982, 1984, 1986, 1989, 1992 and 1994; two in 1985 and 1991; three in 1997; four in 1998; seven in 1999 and 2000; nine in 2001. FERREIRA et al., 1987 , described an outbreak of food botulism and a case of wound botulism that corresponded to the serum samples received in 1985, from Minas Gerais.

The bioassay was performed as described in the Compendium of Methods for the Microbiological Examination of Foods ${ }^{11,20}$. Briefly, separated serum from blood (when blood samples were received), serum, saline solution used to wash the blood clot and organ macerates were directly injected in two mice, intraperitonially; the other samples (feces, gastric washing, foods and drugs) were prepared (toxin extraction) and treated as described by KAUTTER et al., 1992 ${ }^{11}$. White Swiss female 
mice (20-25 g each), provided by the Laboratory Animal Facility at Instituto Adolfo Lutz, were observed closely for the first 6 hours after inoculation and in 3-4 h intervals, until $72 \mathrm{~h}$. When the bioassay was positive for toxic substance compatible with botulinum toxin, the remaining material was submitted to the determination of type of toxin with specific botulinum antiserum types A, B, E and F. These specific antisera came from the Centers for Disease Control, Atlanta, United States. A volume equal to $0.3 \mathrm{ml}$ of antiserum was mixed with $1.2 \mathrm{ml}$ of the material (serum or extract) and kept at $37^{\circ} \mathrm{C}$ for 30 minutes before inoculation. For a better observation of the signs and symptoms of animals - not for toxin quantification - the extracted portion of one of the food sample was diluted in phosphate gel to $1: 100$. The investigation was performed under safety rules already indicated ${ }^{19}$.

\section{RESULTS AND DISCUSSION}

Results obtained in this study are in Table 1. The number of cases / outbreaks was 40 , with 88 samples. From these, 17 , corresponding to 8 among the 40 suspect cases/outbreaks (20\%), were positive for the presence of toxin. Fifteen of them were confirmed as type A toxin, and amount of two samples was not sufficient for the determination of the type of toxin.

From 36 suspect case/outbreaks, $30(83.33 \%)$ were sent to the laboratory with some information. Among these 30 cases, 10 (30\%) presented clinical symptoms compatible with botulism. From the other, two cases presented symptoms compatible with botulism, but with negative laboratory results. One of these samples was collected ten days after the onset of symptoms. For the other, samples serum, feces and gastric washing were collected eight days before the onset of the symptoms; differential clinical diagnosis indicated nervous blockage of muscle.

Some observations are relevant in relation to data in Table 1. Food sample from case 5 presented a great quantity of toxin, what led the sudden death of the mice. The extracted portion had to be diluted to $1: 100$ for a better observation of the signs and symptoms in the inoculated animals. The first serum sample received from outbreak 4 was negative, but the clinical history indicated the administration of antitoxin prior to blood collection. The second sample of this outbreak came from a fatal case, from a person who was also affected after the consumption of the same food. Blood was collected at the moment the patient was admitted in the hospital and this sample was positive. Case number 5 and 6 were confirmed in the laboratory examination (toxin was detected both in the samples of serum and food leftovers). The homemade preserve related to case 3 was also positive (artichoke hearth, eggs, cucumber, etc. preserved in oil and vinegar), despite $\mathrm{pH}$ equal to 3.8. The finding of botulism toxin in $\mathrm{pH}$ under 4.5 is not new and have already been reported $^{21,23}$.

The isolation of Clostridium botulinum from food or biological samples has a limited value in botulism diagnosis. Because this bacterium is commonly found in nature and in feces of people not affected, its isolation should not be considered a significant hazard, or used to diagnose the disease. The isolation of a toxin-producing $C$. botulinum strain is an important tool for the diagnosis of infant botulism, in absence of normal intestinal flora in babies, and of wound botulism, as it is the prevalent bacteria in wound material. Even in these cases, definitive diagnosis is given by the characterization of the toxin circulating in the bloodstream ${ }^{5,20,23}$.

Bioassay is an efficient laboratorial tool to determine the presence of the toxin. As any other laboratorial determination, the whole protocol must be conducted adequately, in order to assure complete and reliable results. The amount of sample must be sufficient to perform all laboratory procedures; the collection of the samples must be related with the time of the onset of symptoms (ideally, as soon as they begin; or maximum eight days after the onset). Blood must be collected before the administration of any drugs that may interfere with laboratorial results, mainly botulinum antiserum. Transport and preservation of the samples must be carried out under refrigeration and in hermetic boxes; and the complete case history related to the sample must be provided, among other factors.

Table 1

Confirmed botulinum toxin by mouse bioassay, according to the origin, number and kind of sample. Suspect samples were not included. Central Laboratory of Instituto Adolfo Lutz, 1982-2001

\begin{tabular}{|c|c|c|c|c|}
\hline Outbreak or case & State & Year & Number/nature of sample & Toxin type \\
\hline 1 & M. Gerais & 1985 & $7 /$ serum $^{(1)}$ & A \\
\hline 2 & M. Gerais & 1985 & $1 /$ serum $^{(1) *}$ & A \\
\hline 3 & S. Paulo & 1991 & $1 /$ food (leftover of home made preserve) & A \\
\hline 4 & Goiás & 1997 & $1 /$ serum $^{(2)}$ & A \\
\hline \multirow[t]{2}{*}{5} & S. Paulo & 1997 & 1/blood clot & A \\
\hline & & & $1 /$ food (leftovers of palm tree preserve, diluted $1: 100$ ) & A \\
\hline \multirow[t]{2}{*}{6} & S. Paulo & 1998 & 1 serum & A \\
\hline & & & $1 /$ food (leftover of palm tree preserve) & A \\
\hline 7 & S. Paulo & 1999 & $1 /$ serum & A \\
\hline \multirow[t]{2}{*}{8} & S. Paulo & 2001 & $1 /$ serum & $\mathrm{P}$ \\
\hline & & & $1 /$ feces & $\mathrm{P}$ \\
\hline
\end{tabular}

(1) Outbreak and case described by FERREIRA et al. ${ }^{6}, 1987 . *$ Wound botulism case; ${ }^{(2)}$ First serum was negative (antitoxin administration); second one (fatal case), was positive; $\mathrm{P}$ = Presumptive positive, typification not performed. Result of mouse bioassay compatible with botulinum toxin. 


\section{RESUMO}

\section{Botulismo: investigação laboratorial de amostras biológicas e de alimentos de casos e surtos no Brasil (1982-2001)}

A investigação laboratorial de botulismo durante 1982-2001, confirma a ocorrência de surtos/casos de botulismo no Brasil. Dentre estes, a toxina botulínica tipo A foi encontrada em 7. O material biológico de 1 caso (soro e fezes) foi positivo para a primeira etapa do bioensaio, mas a quantidade do material não foi suficiente para a sua tipificação. Um surto, ocorrido em 2001, foi negativo para a presença de toxina botulínica em amostras de soro, lavado gástrico e fezes coletadas antes de 8 dias da instalação dos sintomas na pessoa afetada com diagnóstico clínico compatível com a doença. Outros 2 casos com diagnóstico clínico compatível foram negativos, porém nestes a coleta de amostras foi (1) depois da administração de anti-soro ao paciente e (2) em período superior a 8 dias do início dos sintomas. A investigação laboratorial foi realizada por bioensaio em camundongo, conforme descrito no "Compendium of Methods for the Microbiological Examination of Foods" (compilado por "American Public Health Association - APHA")", e pelo uso de anti-soros específicos do "Centers for Disease Control (CDC)", Estados Unidos.

\section{REFERENCES}

1. ARNON, S.S. - Infant botulism: anticipating the second decade. J. infect. Dis., 154: 201-206, 1986.

2. CHIA, J.K.; CLARK, J.B.; RYAN, C.A. \& POLLACK, M. - Botulism in an adult associated with food-borne intestinal infection with Clostridium botulinum. New Engl. J. Med., 315: 239-241, 1986.

3. CONNER, D.E.; SCOTT, V.N.; BERNED, D.T. \& KAUTTER, D.A. - Potential Clostridium botulinum hazard associated with extended shelf life refrigerated food: a review. J. Food Safety, 10: 131-153, 1990.

4. CUPPET, S.L.; GRAY, J.I.; PESTKA, J.J. et al. - Effect of salt level and nitrite on toxin production by Clostridium botulinum type E spores. J. Food Protect., 50: 212-217, 1987.

5. ESCARTÍN, E.F. - Clostridium botulinum. Microbiologia e inocuidad de los alimentos. México, Universidad Autonoma de Queretaro, 2000.

6. FERREIRA, M.S.; NISHIOKA, S.A.; ALMEIDA, A.B. et al. - Botulismo: considerações acerca de oito casos ocorridos no Triângulo Mineiro, Minas Gerais, Brasil. Rev. Inst. Med. trop. S. Paulo, 29: 137-141, 1987.

7. GIBSON, A.M.; ROBERTS, T.A. \& ROBINSON, A. - Factors controlling the growth of Clostridium botulinum types A and B in pasteurized cured meat. IV. The effect of pig breed, cut and batch of pork. J. Food Techn., 17: 471-482, 1982.

8. GRAHAM, A.F. \& LUND, B.M. - The effect of citric acid on proteolytic strains of Clostridium botulinum. J. appl. Bact., 61: 51-56, 1986.
9. ICMSF. INTERNATIONAL COMMISSION ON MICROBIOLOGICAL SPECIFICATIONS FOR FOODS - Clostridium botulinum. In: Microorganisms in foods 5. Characteristics of microbial pathogens. London, Blackie Academic and Professional, 1996. p. 66-111.

10. JAY, J.M. - Modern food microbiology. 4. ed. New York, Chapman \& Hall, 1992.

11. KAUTTER, D.A.; SOLOMON, H.M.; LAKE, D.E. et al. - Clostridium botulinum and its toxins. In: VANDERZANT, C. \& SPLITTSTOESSER, D.F., ed. Compendium of methods for the microbiological examination of foods. 3 ed. Washington, American Public Health Association, 1992.

12. LAWLOR, K.A.; PIERSON, M.D.; HACKNEY, C.R. et. al. - Nonproteolytic Clostridium botulinum toxigenesis in cooked turkey stored under modified atmospheres. J. Food Protect., 63: 1511-1516, 2000.

13. LYON, W.J. \& REDDMANN, C.S. - Bacteria associated with processed crawfish and potential toxin production by Clostridium botulinum type E in vacuum-packaged and aerobically packaged crawfish tails. J. Food Protect., 63: 1687-1696, 2000.

14. McCROSKEY, L.M. \& HATHEWAY, C. L. - Laboratory findings in four cases of adult botulism suggest colonization of intestinal tract. J. clin. Microbiol., 26: 1052-1054, 1988.

15. NOTERMANS, S.; DUFRENNE, J. \& GERRITS, J.P.G. - Natural occurrence of Clostridium botulinum on fresh mushrooms (Agaricus bisporus). J. Food Protect., 52: 733-736, 1989

16. SAKAGUCHI, G. - Botulism. In: RIEMANN, H. \& BRYAN, F.L., ed. Foodborne infections and intoxications. 2. ed. New York Academic Press, 1979.

17. SAYLERS, A.E. \& WHITT, D.D. - Disease without colonization: food-borne toxinoses caused by Clostridium botulinum, Staphylococcus aureus and Clostridium perfringens. In: Bacterial pathogenesis: a molecular approach. Washington, ASM Press, 1994.

18. SHIBAMOTO, T. \& BJELDANES, L.F. - Introduction to food toxicology. New York, Academic Press, 1993. p. 5.

19. SOLOMON, H.M. \& LILLY Jr., T. - Clostridium botulinum. In: Bacteriological analytical manual on line. Washington, Food and Drug Administration, 1998. http:// www.cfsan.fda.gov/ ebam/bam-17.html.

20. SOLOMON, J.M.; JOHNSON, E.A; BERNARD, D.T.; ARNON, S.S. \& FERREIRA, J.L. - Clostridium botulinum and its toxins. In: DOWNES, F. P. \& ITO, K., ed. Compendium of methods for the microbiological examination of food. 4 . ed. Washington, American Public Health Association, 2001.

21. TANAKA, N. - Toxin production by Clostridium botulinum in media at $\mathrm{pH}$ lower than 4.6. J. Food Protect., 45: 234-237, 1982.

22. TSANG, N.; POST, L.S. \& SOLBERG, M. - Growth and toxin production by Clostridium botulinum in model acidified systems. J. Food Sci., 50: 961-965, 1985.

23. VARNAM, A.H. \& EVANS, M.G. - Clostridium botulinum. Foodborne pathogens an illustrated text. St. Louis; London, Brook House; Wolfe, 1991.

Received: 27 March 2002

Accepted: 12 September 2002 